\title{
POTENSI PULAU MOLOSING DI BOLAANG MONGONDOW SEBAGAI KAWASAN WISATA
}

\author{
Marnix L.D. Langoy ${ }^{1)}$ dan Saroyo ${ }^{1)}$ \\ ${ }^{1)}$ Program Studi Biologi FMIPA Universitas Sam Ratulangi, Manado 95115 \\ e-mail: saroyos@yahoo.com
}

\begin{abstract}
ABSTRAK
Pulau Molosing yang terletak di Kabupaten Bolaang Mongondow dapat dikembangkan sebagai daerah tujuan wisata berbasis alam. Hal ini disebabkan karena adanya dua potensi yang paling penting, yaitu keanekaragaman hayati dan asesibilitasnya. Beberapa jenis habitat ditemukan di pulau tersebut yang meliputi terumbu karang, formasi pantai, bakau, dan hutan hujan. Pengunjung dapat menggunakan perahu dari desa terdekat untuk mencapai pulau tersebut.
\end{abstract}

Kata kunci: Kabupaten Bolaang Mongondow, Pulau Molosing, wisata berbasis alam.

\section{POTENCY OF MOLOSING ISLAND IN BOLAANG MONGONDOW DISTRICT AS TOURISM AREA}

\begin{abstract}
Molosing Island that was located in Bolaang Mongondow District can be developed as naturebased tourism destination. Because of two important aspects i.e. biodiversity and accessibility. Many kinds of habitat can be found in this island, such as coral reef, beach formations, mangrove, and rainforest. Visitors can use the boat from the nearest village to reach this island.
\end{abstract}

Keywords: Bolaang Mongondow District, Molosing Island, nature-based tourism.

\section{PENDAHULUAN}

Kekayaan sumber daya alam yang beraneka ragam apabila dikelola dan dikembangkan dengan baik akan mempunyai peranan yang sangat penting bagi pengembangan pariwisata, khususnya wisata alam. Wisata alam adalah kegiatan perjalanan atau sebagian kegiatan tersebut yang dilakukan secara sukarela serta bersifat sementara untuk menikmati gejala keunikan dan keindahan alam.

Pulau Molosing di Kabupaten Bolaang-Mongondow merupakan satu kawasan yang memiliki potensi untuk dikembangkan sebagai daerah tujuan wisata karena memiliki potensi sumber daya alam hayati yang cukup baik serta asesibilitas yang mudah untuk mencapai lokasi tersebut.

Dengan potensi sumber daya alam hayatinya yang meliputi terumbu karang, vegetasi pantai, mangrove, dan hutan huja tropis dengan beberapa fauna di dalamnya, Pulau Molosing dapat dikembangkan sebagai kawasan untuk wisata ekologis atau wisata berbasis alam yang berkait dengan pendidikan dan pemahaman lingkungan alam dan dikelola dengan prinsip berkelanjutan.

Sampai saat ini informasi tentang Pulau Molosing masih sangat kurang, terutama dari sudut ekologi. Informasi yang tersedia lebih banyak menyoroti masalah keindahan pulau dan akses menuju pulau tersebut. Oleh karena itu, tulisan ini disajikan sebagai referensi awal tentang keanekaragaman hayati dan potensi kepariwisataan Pulau Molosing.

\section{METODE PENELITIAN}

Metode dalam penelitian ini adalah survei eksploratif dengan mengunjungi Pulau Molosing di Kabupaten BolaangMongondow pada tanggal 4 Juli 2010. Data fisik yang diukur adalah koordinat satu titik pada pantai, suhu (pukul 10.16 WITA), dan kelembaban. Data dan informasi dikumpulkan secara langsung dari pengamatan dan informasi dari masyarakat dan nelayan di desa terdekat dengan pulau. 
Data yang diamati meliputi tipe-tipe habitat dan vegetasi penyusunnya serta fauna yang dijumpai pada lokasi. Hasil pengamatan diuraikan secara deskriptif.

\section{HASIL DAN PEMBAHASAN}

Pulau Molosing terletak di Kabupaten Bolaang-Mongondow. Pulau dengan luas sekitar 200 ha ini hanya berjarak sekitar setengah kilometer dari pantai terdekat di Kecamatan Lolak. Tampaknya pulau ini dihasilkan dari aktivitas vulkanik atau tektonik karena dikelilingi oleh batuan vulkanik. Survei pada satu titik, diketahui koordinatmya adalah $\mathrm{N} \quad 00^{\circ} 54,011$ ' $\mathrm{E}$ $123^{\circ} 58,588^{\prime}$ dengan suhu $29,9{ }^{\circ} \mathrm{C}$ (pukul 10.16 WITA) dan kelembaban 55\%.

\section{Tipe Habitat}

Pulau Molosing (Gambar 1) memiliki beberapa tipe habitat, yaitu terumbu karang, vegetasi pantai, hutan mangrove, dan hutan hujan. Terumbu karang di sekitar pulau ini masih terawat dengan baik, dan memiliki keragaman hayati yang tinggi. Informasi nelayan menyebutkan bahwa masyarakat berperan serta dalam menjaga kelestarian terumbu karang di sekitar pulau. Pencarian ikan dilakukan di lokasi yang jauh dari Molosing.

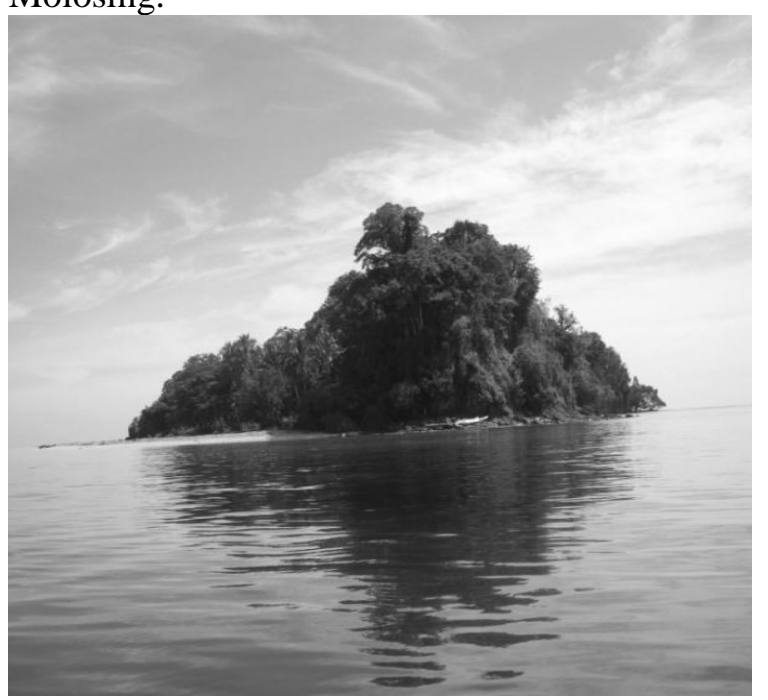

Gambar 1. Pulau Molosing

Vegetasi pantai dapat dibedakan menjadi dua macam formasi, yaitu formasi pes-caprae dan formasi baringtonia. Formasi pes-capare dicirikan dengan tumbuhan tapak kambing (Ipomoea pes-capare) dan kacang pantai (Vigna marina). Formasi barringtonia dicirikan dengan beberapa tumbuhan, antara lain ketapang (Terminalia catappa), nyamplung (Callophylum inophylum), Pongamia sp., Pandanus, dan bugis (Melia azedarach).

Habitat mangrove hanya meliputi sekitar $100 \mathrm{~m}$ garis pantai dengan dasar perairan berbatu. Vegetasi habitat ini didominasi oleh Bruguiera dan Rhizophora. Lingkungan mangrove ini menjadi habitat bagi berbagai fauna perairan dan burung (Whitten et al., 1988). Walaupun tidak luas, hutan mangrove ini dapat menjadi peredam gelombang dan angin badai, pelindung dari abrasi, penahan lumpur dan perangkap sedimen (Bengen, 1999).

Hutan hujan pada pulau ini masih cukup baik dengan beragamnya vegetasi yang tumbuh di perbukitan dengan dominasi kayu kambing (Garuga floribunda) dan kelapa (Cocos nucifera) serta mangga (Mangifera indica) yang kemungkinan diintroduksi oleh nelayan dan pemilik lahan. Sebagai hutan hujan, kawasan ini juga memiliki sejumlah liana dan epifit, antara lain anggrek (Orchidaceae) dan paku (Pterydophyta).

\section{Fauna}

Walaupun hanya pulau kecil, Molosing memiliki beragam fauna, antara lain serangga, burung, dan mamalia. Selama survei, di lokasi ini ditemukan elang bondol (Haliastur indus), gagak (Corvus enca), tuwur Sulawesi (Eudynamis melanorhyncha), dan belibis (Dendrocycna arcuata). Belibis kemungkinan menggunakan kawasan pulau ini hanya sebagai tempat istirahat atau tidur saja, dan akan terbang ke daratan utama Sulawesi dalam aktivitas hariannya, terutama lokasi-lokasi berair, seperti sungai dan rawa. Memang habitat burung jenis ini adalah payau air tawar, danau-danau, laguna, dan rawa-rawa (Coates \& Bishop, 2000). Berdasarkan informasi penduduk, pulau ini juga menjadi tempat peneluran burung maleo (Macrocephalon maleo). Maleo adalah megapoda yang karena ukuran telurnya sangat besar, maka mereka menimbun telurnya di tanah yang dekat dengan aktivitas geotermal (Lee et al., 2001). Oleh karena itu, jika informasi nelayan ini benar, maka Pulau Molosing berada pada lokasi dengan aktivitas geotermal seperti Tambun di Taman Nasional Bogani Nani Wartabone. Ular piton 
(Phyton reticulatus) juga sering dijumpai di Molosing. Mamalia yang hidup di Molosing, antara lain bajing (Sciurus sp.) dan monyet. Walaupun dalam survei tidak menjumpai primata ini, berdasarkan informasi nelayan beberapa monyet Gorontalo (Macaca nigrescens) sengaja dilepas di Molosing.

Sebagaimana karakteristik pulau-pulau kecil lainnya, Pulau Molosing di samping memiliki nilai ekologis yang tinggi, tetapi juga peka dan rentan terhadap pengaruh eksternal baik alami maupun kegiatan manusia, misalnya badai dan gelombang besar, serta pencemaran (Bengen, 2002).

\section{Potensi Wisata}

Untuk menjadi daerah tujuan wisata, dua persyaratan utama yaitu potensi alam dan asesibilitas bagi Pulau Molosing cukup memadai. Keindahan pantai, kekayaan hayati dan keindahan terumbu karang, serta keragaman flora fauna dapat menjadi daya tarik wisata maupun petualangan. Beberapa kegiatan yang dapat dilakukan di pulau ini antara lain menyelam, snorkeling, camping, dan pengamatan burung (birdwatching).

Akses untuk mencapai Pulau Molosing (Gambar 2) juga sangat mudah karena terletak di Ibu Kota Bolaang-Mongondow dan untuk menuju pulau dapat ditempuh dengan menggunakan perahu katinting nelayan selama sekitar 15 menit. Di kampung terdekat Molosing juga tersedia penginapan yang letaknya cukup strategis.

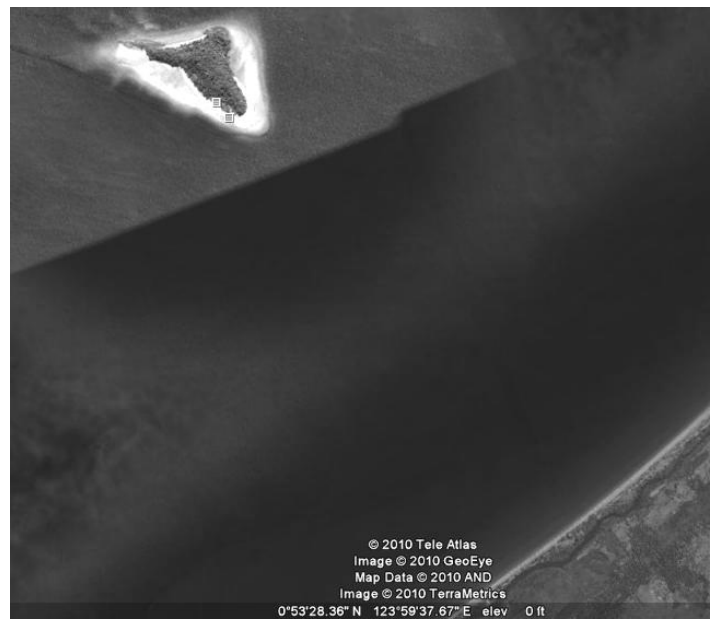

Gambar 2. Potret Satelit Pulau Molosing (Google Earth)

Pengembangan suatu kawasan sebagai daerah tujuan wisata berbasis alam ini menuntut dipenuhinya berbagai kriteria, antara lain: memiliki keunikan alam, memiliki atraksi budaya menarik, kesiapan masyarakat lokal, peruntukan kawasan jelas, prasarana minimal (akomodasi, pangan) sudah ada, dan aksesibilitas minimal untuk menunjang pengembangannya (Ditjend Pariwisata, 1998).

\section{KESIMPULAN}

Dari hasil dan pembahasan di atas dapat disimpulkan bahwa Pulau Molosing di Kabupaten Bolaang-Mongondow memiliki potensi, baik sumber daya alam hayati maupun asesibilitas untuk dikembangkan sebagai kawasan wisata berbasis alam.

\section{DAFTAR PUSTAKA}

Bengen, D.G. 1999. Pedoman Teknis Pengenalan dan Pengelolaan Ekosistem Mangrove. Pusat Kajian Sumberdaya Pesisir dan Lautan, Institut Pertanian Bogor. Bogor.

Bengen, D.G. 2002. Sinopsis Ekosistem dan Sumberdaya Alam Pesisir dan Laut serta Prinsip Pengelolaannya. Pusat Kajian Sumberdaya Pesisir dan Lautan, Institut Pertanian Bogor. Bogor.

Coates, B.J. and K.D. Bishop. 2000. Panduan Lapangan Burung-Burung di Kawasan Wallacea: Sulawesi, Maluku dan Nusa Tenggara. BirdLife Internasional Indonesia Programme \& Dove Publication Pty.Ltd. Bogor.

Ditjend Pariwisata. 1998. Pedoman Pengembangan Ekowisata. Jakarta.

Lee, R.J., J. Riley, \& R. Merrill. 2001. Keanekaragaman Hayati dan Konservasi di Sulawesi Bagian Utara. WCS-IP dan NRMJ. Jakarta.

Whitten, A.J., M. Mustafa, and G.S. Henderson. 1988. The Ecology of Sulawesi. Gadjah Mada University Press. Yogyakarta. 